\title{
Subject Element Code
}

National Cancer Institute

\section{Source}

National Cancer Institute. Subject Element Code. NCI Thesaurus. Code C83275.

A character or string that represents a subject element. 